\title{
Organization of Cost Accounting of Fur Farming in Controlling Concept
}

Klychova G.S

Kazan State Agrarian University, Karl Marx str., 65, Kazan, 420015

Safiullin N.Z.

Kazan (Volga Region) Federal University", Kremlyovskaya str., 18, 420008, Kazan,

Zakirova A.R.

Kazan State Agrarian University, Karl Marx str., 65, Kazan, 420015

Doi:10.5901/mjss.2014.v5n18p219

\begin{abstract}
In this paper we study controlling as internal management of organization system by creating a specific plan-monitoring mechanism for informational and analytical support, coordination and integration of all management subsystems to achieve the organization goals for its sustainable and efficient functioning and development. The forms of controlling registers are offered as a way of forming factual information to manage costs and profits within the controlling concept of fur farming.
\end{abstract}

Keywords: Fur farming, controlling, costs, accounting and analytical register, price.

\section{Introduction}

Integration of world economies leads to further intensification of competition within the country due to the admission of foreign companies doing business in equal conditions with domestic producers. Market economy has "forced" foreign companies to implement such tools into their management systems that allow them to survive in the competition; and those, who failed to accept new approaches to management, have bankrupted and have been forced to leave the market. One of the said main tools is controlling $[1,5]$. Therefore, domestic organizations essentially need introduction of controlling into their practice to survive in conditions of increasing competition.

The main advantage of controlling is that it can accurately and flexibly solve the main problems of entrepreneurship - pricing of products, acceptance or exclusion of certain types of products from production program, maximization of profit, etc.

The most important feature of the new system is its focus on management. The system is organized so that the user is not limited to only partial monitoring of the managed object, but systematically analyzes its condition, identifies deviations, prepares and makes decisions $[3,9,12]$. The composition of problems to be solved is determined by complexity and objectives of management of the organization.

\section{The Essence of Controlling as a System of Enterprise Internal Management}

Controlling is a new phenomenon in the theory and practice of modern management, which occurred at the intersection of economic analysis, planning, management accounting and management [1]. Controlling system is a synthesis of elements of accounting, analysis, monitoring, planning, implementation of which ensures the production of alternative approaches in implementation of operational and strategic management of ultimate goals and performance of the company. [2]

The concept "controlling" comes from the English verb "to control", which is polysemantic. In economic terms, it is management and monitoring. But since the effective management and supervision are impossible without setting goals and planning measures for realization of these objectives, controlling comprises a complex of tasks on planning, management and monitoring. [3]

According to the modern approach, controlling can be interpreted as information support of results-oriented enterprise management. Controlling tasks, therefore, include preparing and providing the necessary management 
information to orient the company's management to making decisions and actions required. Thus, the main function of controlling is to support the company's management $[4,11]$.

In some literary sources, controlling is defined as one of sub-functions of entrepreneurship, which not only prepares decisions, but also provides support for their implementation $[5,9]$.

The German economic literature contain other points of view on the essence of goals and objectives of controlling. Thus, P. Horvath interprets controlling from the point of company goals. Therefore, he believes that controlling must realize management of the company by information and support it in coordination, response and adaptation to changing internal and external conditions in implementation of the planned objectives $[5,8]$.

Kh.Yu. Küpper approaches the controlling from the different position. He sees the central task of controlling in coordination of enterprise management system. The necessity in coordination function follows from separation of management system into components. Among such components he singles out: organization, planning and control system, information system, personnel management system, system of goals and principles of management. Thus, performing coordinating function controlling contributes to the achievement of not one goal of the enterprise, but of a system of goals. Besides, cost target values are emphasized. However, Küpper notes that in such broad interpretation of controlling there is a danger that its tasks could become all-inclusive and there will be problems in their separation from the other subsystems of the management [5].

J. Weber, basing on the concept of controlling of Horvath and Küpper, contemplates controlling primarily as a tool for coordination. In his interpretation, controlling is an element of social system management, performing its main function of management support in the process of solving the general problem of management system coordination with primary focus on the tasks of planning, monitoring and informing. At the same time Weber, as well as Küpper, emphasize that controlling is not associated with the process of goal setting (for example, setting the profit goals).

From the foregoing, it appears that controlling is the shortest method of operational management information delivery to the management system. The working tool of such information delivery is the persistent scheduling and replacement of static plans by possibly dynamic plans, most close to the rapidly changing market environment $[6,10]$. The mechanism of this tool is management and financial accounting, analysis, preparation of plans and coordination of these elements operation.

Thus, in our opinion, controlling is the system of internal management of organization by creating a specific planmonitoring mechanism for informational and analytical support, coordination and integration of all management subsystems to achieve the organization's goals for its sustainable and efficient functioning and development.

\section{Controlling is the Basis of Cost and Results of Operational and Financial Activities Management}

The basis of this concept implementation is seen by specialists in organizing the internal structure of organization, functioning by cycles of self-regulation (cycle: deviation - eliminating of deviation), which allows large enterprises to simplify the management and control system. The idea of self-regulation in controlling is simple and based on the principle of management by exception, the essential part of which is accounting and analytical information on deviations of factual data from the standard ones. If eliminating of deviation is in the competence of the division, and the higher authorities are not involved, this is what precisely self-regulation means.

Considering the accounting aspect of controlling, the movement of management data can be represented in two ways. On the one hand, information is generated by accounting and controlling service within the company and sent to the management system. On the other hand, information is generated by accounting and controlling service on the basis of the external environment and also sent to the management system. In addition, the synthesis of these data flows takes place, and there from the financial result is detected. The latter presented by accounting controlling service is the endpoint of information traffic in the management system of profit formation. At the same time, the information provided for management system of accounting and controlling service, according to the concept of controlling must bear certain recommendations, will guide the management in making the right long-term and life-organization decisions.

According to the analysis of information the counter stream, the accounting and controlling service can offer, respectively, two schemes to the management - to change the information flow received within the organization or to change information stream obtained from the environment (in practice, a combination of these schemes). Change of the information stream obtained from the environment, actually implies the change in marketing activities, which in their turn, respectively shall provide maximum opportunity to maintain high prices and sales volumes [7].

The main signal in the information flow from the environment is a price change or forecast in its change on the basis of certain factors. Here the task of accounting and controlling service is relevant registration of the "new price" fact, deviation from the planned price, reasons for this deviation followed by the appropriate activities offer. The proposed 
activities are determined by the field of industry, in which the organization operates. For industries, where production volumes are regulated without too much difficulty, by simple reduction in production, the way the controlling system clearly manifests itself as the concept of combining the registration of economic life fact with development of management decision. For such industry as agriculture, the concept in the usual form is no longer applicable.

If you need to change production in the short term plan, agriculture needs at least a whole year. Greater restrictions on the use of controlling in organizations are also imposed by specific nature of various agricultural production fields, in particular, fur farming. It is relatively difficult to increase production quickly in case of necessity. On the other hand, the decline in production of organization can jeopardize the existence of the farming industry. This fact shows that efficiency is out of question; and controlling is not needed here, because we have a whole year for the needs of the production program changing in terms of fur production, when we can routinely analyze data, deliver it to the management system, wait for the decision, etc.

However, price change does not determine the need for changes in production volumes. This fact should target the management system, especially to marketing change, particularly, changing sales channels, advertising increase etc. This aspect of controlling is naturally applicable in fur farming.

Another feature of the fur farming industry is the possibility of long-term skins storage, which creates conditions for formation of a buffer against rising demand for these products or retirement of excessive turnover of products in case of fall in demand, so as not to cause a decline in prices, for example in a region where the organization is or is not to incur losses in connection with the sale of skins at reduced prices.

The latter point shows the possibility of a rapid response to changing information flows from the environment that requires even more to apply the system of controlling in organizations engaged in fur production. The basis for the response should be deviations from the planned data. In the controlling system the data is processed in indexes, on its basis the system under consideration operates.

In this paper, the emphasis is placed on accounting component of controlling. In this connection, marketing controlling will not be considered. The only index that is the link between accounting subsystem of controlling and marketing controlling is the unit price of the product - one animal skin.

Table 1. Profitability of controlling of fur farming on December, 20xx

\begin{tabular}{|l|c|c|c|c|}
\hline \multirow{2}{*}{ Type of skins } & \multicolumn{2}{|c|}{ Profitability of variable costs, \% } & \multicolumn{2}{c|}{ Profitability of fixed costs, \% } \\
\cline { 2 - 5 } & plan & fact & plan & fact \\
\hline Mink & 25 & 31,6 & 110 & 126,4 \\
\hline Arctic fox & 15 & 27,1 & 105 & 108,4 \\
\hline Fox & 25 & 33,3 & 110 & 133,1 \\
\hline Sable & 50 & 104,1 & 200 & 416,5 \\
\hline Total & 25,0 & 38,5 & 120 & 153,8 \\
\hline
\end{tabular}

Controlling cycle in this form also relates to all previous registers considered above. This means that all registers of controlling not mentioning specifically the periods (cycles) of planning (planning data) and reporting (actual data), should be compiled every time upon completing of the controlling cycle. For this, two copies of controlling register should be compiled:

- the first copy indicates the values of specified targets set in the previous period as a benchmark for the current period, and the actual values obtained at the end of the current period;

- the second copy indicates only planned values of indexes set on the basis of the first copy and current operational forecasts. As a result, the first copy becomes the report of the work performed, and the second the benchmark for events in the current period.

\section{Conclusion}

Thus, controlling may be interpreted as information provision oriented at the enterprise management result. Controlling tasks, therefore, guide the company's management decisions and actions by preparing and providing the necessary management information. Consequently, the main function of controlling is to support the company's management.

Controlling is considered as delivery of operational management information in the shortest way to the management system. Working tool of such delivery is persistent scheduling information and replacement of static plans by possibly dynamic plans, most close to rapidly changing market environment. Mechanism of this tool is management 
and financial accounting, analysis, preparation of plans and coordination of these elements operation.

From this we can determine that controlling is the system of internal management of organization by creating a specific plan-monitoring mechanism for informational and analytical support, coordination and integration of all management subsystems for the organization's goals achievement of its sustainable and efficient functioning and development.

\section{References}

Popova L.V., Isakov R.E., T. Golovin, 2003. Controlling. Moscow: Publishing House "Business and Service", 192p.

Kirshin I.A., Datsyk A.A., Titov A.V. Forecasting the Dynamics of an Innovative Cycle. - World Applied Sciences Journal (Economics, Management and Finance). - 2013. - №27. - P. 197 - 201.

Glebova I.S., Sadyrtdinov R. and Rodnyansky D. Impact Analysis of Investment Attractiveness of the Republic of Tatarstan on Fixed Investments of its Leading Companies // World Applied Sciences Journal 26 (7): 911-916, 2013.

Safiullin L.N., Gafurov I.R., Safiullin N.Z., Bagautdinova N.G. Distribution and product selection under uncertainty / Recent Trends in Social and Behaviour Sciences - Proceedings of the 2nd International Congress on Interdisciplinary Behavior and Social Sciences 2013, ICIBSoS 2013 PP. $309-313$.

Petrenko S.N., 2004. Controlling. K. : Nick Center, Elga, 328 p.

Ivashkevich V.B. Zaitsev S.N., 1996. Controlling at the enterprises of Federal Republic of Germany. Accounting. № 10, P. 76-80.

Gabler. Wirtschafts-Lexikon, Auflage, 1988 Betriebswirtschaftlicher Verlag Dr. Th. Gabler GmbH, Wiesbaden.

Han D., Hungenberg H. Pik, 2005 Value-oriented controlling concept. Moscow: Finance and Statistics, 928 p.

Bagautdinova, N.G., Eshugova, S.K., Saipullaev, U., Karasik, E.A. Methods of technology commercialization in projects of the agrofood system (AFS) development // World Applied Sciences Journal, 27(13), 2013, 48-52.

Hadiullina, G.N., Nugumanova, L.F., Bagautdinova, N.G., Averiyanov, B.A. Transformation of the households functions in the modern Russian economy // World Applied Sciences Journal, 27(13), 2013, 111-115.

Safiullin, N.Z., Safiullin, L.N. (2013) The measure proximity in welfare theory // World Applied Sciences Journal 26 (4) PP. 449 - 453, doi: 10.5829/idosi.wasj.2013.26.04.13472

Novenkova A.Z., Gafurov I.R., Kalenskaya N.V. Marketing of Educational Services: Research on Service Providers Satisfaction II Procedia Economics and Finance, Volume 5, 2013, Pages 368-376. 